\title{
When "Inclusion" Means "Exclusion": Discourses on the Eviction and Repatriations of Roma Migrants, at National and European Union Level
}

\author{
Dragos Ciulinaru ${ }^{1,2}$ (D)
}

Published online: 19 June 2018

(C) The Author(s) 2018

\begin{abstract}
The paper examines the ways and processes of creating exceptions to the enforcement of human rights law in the case of the Eastern European Roma migrants within the European Union. It uses as case study the 2010 campaign of Roma migrants' evictions and repatriations from France, and the related events that followed over a period of six years. The analysis of the discourses of French and European Union officials in relation to the evictions and repatriations highlights the relationships between the discursive construction of unwanted categories of migrants, and migration policy making by national governments and at a European Union level. The main argument is that these evictions and repatriations were primarily a fundamental rights issue due to the discriminatory dimension it was given by those proposing and applying it. However, the issue of discrimination became secondary in the debates which rather focused on the exceptional nature of the Roma and framed this population as an exception from human rights law enforcement. Concomitantly, the discourses made a shift from protection against discrimination to the issue of integration. The analysis examines the implications this shift had on diminishing the responsibility of national and EU authorities for protection against discrimination.
\end{abstract}

Keywords Eastern European migrants $\cdot$ Roma $\cdot$ Expulsions $\cdot$ Discrimination

Highly controversial measures such as expulsions as well as borderline legal measures in curbing Westward migration of Roma ethnics have been documented throughout Europe (Bigo et al. 2013; Tervonen and Enache 2017) before and after the accession of Eastern European member states. Some scholars name these measures an attempt to

Dragos Ciulinaru

dragos.ciulinaru@gmail.com

1 Faculty of Philosophy, University of Bucharest, 204 Splaiul Independentei, 060024 Bucharest, Romania

2 Centre for Migration Law, Radboud University, Nijmegen, the Netherlands 
curb a "free movement of poverty" (Fekete 2014) and liken these legislation and policies to earlier vagrancy laws regulating the mobility of racialised Roma migrants (Tervonen and Enache 2017). Huub Van Baar (2014) considers attempts to curb migration of the Roma as newly emerged mechanisms of bordering the European Union. Economic and ethnic factors work together in the elaboration and in the enactment of immigration rules. It is hard to establish which of the two plays the important role (Melis 2001). Bridget Anderson argues that migration is a problem as long as what is at stake is the migration of the poor (Anderson 2013).

This paper uses as case study the 2010 campaign of Roma migrants' evictions and repatriations from France, and the related events that followed over a period of six years. Even before the French campaign of repatriation of Roma migrants in 2010, authorities in European Union countries had made use of expulsion of Romanians under the provisions of Directive 2004/38/EC. In the current case, the issue at stake is the targeting for eviction and expulsion of a particular ethnic group. The ethnic targeting of Roma migrants was confirmed by a document circulated by the French Ministry of Interior which was leaked to the media. In this document, the state representatives in the departments received the indication to give priority to the Roma settlements as the primary objective of the evictions and expulsions. On the 5 th of August 2010, police chiefs received from the Interior Minister the message that:

Three hundred camps or illegal settlements must be evacuated within three months; (...) "it is down to the prefect in each department to begin a systematic dismantling of the illegal camps, particularly those of the Roma" (The Ministry of Interior 2010).

This article questions whether, in order to pursue its policy of evacuation and expulsions, the French Government interpreted the European legislation on the free movement of EU citizens in a way that justified disregarding protection against discrimination. An ethnic argument for evictions and repatriations contradicts not only the stipulations of the Citizen's Rights Directive, but also the constitutive principles of the European Union, as well as fundamental rights (European Parliament resolution of the 9th of September 2010). Given the EU's potential normative power for defending cosmopolitan values of tolerance and integration (Manners 2003), one would have expected a fast response from the EU's authorities regarding the French Governments campaign of evictions and repatriations. I will argue in the following sections that once embroiled in the high politics of the Union, the issue of full enforcement of human rights legislation for the Roma migrants became a secondary aspect of the situation. The resolution of the whole affair involved a tacit agreement that exceptional measures in breach of the human rights principles of the Union, continue be taken against the Roma.

The paper examines the relationships between reaffirmation of the exclusionary public discourses on the exceptional nature of the Roma, and discriminatory policy making in France and in the EU as a whole. The focus of analysis is on how prejudice against the Roma took over the debate about their discrimination as migrants, and how it framed this population as an exception from human rights law enforcement. Of particular importance is the shift in discourse from protection against discrimination to integration, and the implications this shift had on diminishing the responsibility of 
national and EU authorities for protection of migrants from discrimination. Highlighting these discursive practices helps better accounting "for the ways in which discriminatory attitudes are (re)affirmed as a result of the dialectical relationship between, on the one hand, prejudiced essentializations and "progressive" equality notions within mainstream politics such as "inclusion" and "integration"", and, on the other hand, "apparently neutral practices such as institutional law making"” (Martínez Guillem 2011). The interaction between these practices fosters discrimination in different ways, and ultimately creates a de facto category of European Union "internal outsiders" (Triandafyllidou 2001) who is excluded from the protection of human rights law.

\section{Data and Methods}

The current Roma immigration scare is an interpretation in a contemporary European setting of long-held discourses about the invading Gypsies. By approaching essentialist group beliefs as social acts performed in discourse (Haslam et al. 2000; Verkuyten 2003), this analysis focuses on how various linguistic devices and specific constructions are used to represent the Roma as a homogeneous, distinct, and unchangeable group, in order to legitimate dominance and exclusion (Van Dijk 1984; Essed 1991). The data is approached as discursive events. The discourse historical approach [DHA] (Riesigl and Wodak 2009) is employed to locate discursive practices and strategies in the specific socio-political context, namely the institutional frames of the evictions campaign and its broader socio-political and historical context. For the latter are relevant the French Government's stance on migration, the relation between the French Government and the European Commission, as well as the two institutions' response to the dominant attitudes towards economically non-active migrants from Eastern Europe. The paper mirrors the declarations concerning Eastern European Roma migrants by the French Presidents in 2010 and 2016. On the other hand, the discourses at a national level are mirrored with those at European Union level, in an attempt to identify how these discourses relate to one another.

The texts collected were produced across a period of six years. The first category of data is texts produced directly in relation to the 2010 campaigns of evictions and expulsions of the migrant Roma: declarations of the French President and of the French Ministers, the declarations of European Union officials, especially the official statements of Commissioners, the resolutions of the European Parliament. Of central importance in this category of data were the discourse of President Sarkozy in Grenoble, which marked the beginning of the eviction campaign, the documents and declarations issued by the French Ministry of the Interior in relation to the evictions, and the statements of Viviane Reding, Vice-President of the European Commission, EU Commissioner for Justice, Fundamental Rights and Citizenship. In addition to these, there were collected the subsequent official declarations of the French Presidents regarding the situation of the migrant Roma from Eastern Europe. At the level of European Union institutions, for the period after 2010, the main source of data were the yearly reports on the EU Framework for National Roma Integration Strategies up to 2020.

The analysis looks at the intertextual and interdiscursive relation between utterances. It is possible to follow the representation of the events in 2010 in the texts from subsequent years, the use of the same concepts with different meanings so that it fits the desired political results, the replacement of one particular term with another so that it 
diminishes the legal responsibility of one party. Of particular interest is the substitution of the theme of discrimination with that of inclusion and or integration in the home country. In terms of interdiscursive relation, the reference to the historic discourses on the Roma population is analysed, especially reference to those discourses that emphasised the Roma's exceptional, different, and dangerous nature.

The departure point for analysing each text is that of the immediate language or text internal co-text. In line with the DHA approach, the analysis distinguishes between three dimensions which constituted textual meanings and structures. First, each text refers to a number of topics: what is that the text speaks about, for example the migrants, illegal settlements etc.. Secondly, there are the presuppositions that underpin the discursive strategies (Chilton 2004); and the linguistic means that were drawn upon to realise both topics and strategies. Nonetheless, the analysis looks at how the claims in the text are justified through content-related warrants used to connect arguments with conclusions (Richardson and Wodak 2009).

\section{The Discourse of the Exceptional Nature of the Roma}

At first sight, it is unclear how the events during the summer of 2010 in France became an Eastern European Roma issue. No Roma migrant was involved at the beginning. There were two separate events in which French citizens were involved. On the 15th of July 2010 near Grenoble, police killed Karim Boudouda, after he and an accomplice robbed a casino and fired gunshots at the forces of order. The second event involved the killing by the police of a French citizen belonging to a group of "travellers" [gens $d u$ voyage]. The person in case, Luigi Duquenet, had failed to stop at a checkpoint and bumped into a police officer. Both events were followed by violent confrontations between groups of local youths and the police at Grenoble (Euronews 2010) and at Saint-Aignan respectively (Liberation 2010).

On the 30th of July 2010 with the occasion of the swearing in of a new préfet for the Isere department, Nicolas Sarkozy went to Grenoble and gave a speech in which he linked the recent violent events to the launch of a new security policy of the Government. The French President talked of this policy as of a "war against the traffickers and the delinquents" (Discours de M. le Président 2010). The discourse of the French President interpreted the events in Grenoble, especially the attack against the police, as proof of "a problem of mobsters", of "values which are disappearing" and as threats "to the basis of the French society: the republican order" (Discours de M. le Président 2010).

The Roma were introduced in a subtle way into President Sarkozy's equation for "a war against traffickers and mobsters" (Discours de M. le Président 2010). The declarations rejected any intention to target the Roma, but this was done in between arguments that did the opposite. The President recalled the much controversial phrase "La France ne peut accueillir toute la misère du monde" of Michel Rocard and then labelled it as a "reasoned observation" (Discours de M. le Président 2010). He then went on to talk about the presence in France of foreigners in irregular situations, who should be returned to their countries of origin. The Roma came into discussion through comparing an illegal residence in France with an illegal placement of a camp. To make the association more dramatic, the illegal setting of camps was termed as "savage" (Discours de M. le Président 2010). 
Also as an argument for the need to take action were mentioned the already good intentions of the Government which had provided more camping spaces for travellers. The President implied that the Roma had not answered in a similar manner to the good intentions of the Government, given the 539 illegal camps found in France at that moment. Hence, the Roma who did not come to France to install themselves in legal places were not welcome anymore. Targets were also announced. Namely, in three months, half of the illegal camps were estimated to vanish. Not only that President Sarkozy promised the enforcement of judicial decisions and the dismantling of camps for the eviction of which existed an order of the courts, but he went on and promised actions with much wider implications. In order to set into action his plan of banning from France the irregulars, Sarkozy hinted at a plan of a renegotiation of the European citizenship legislation.

The discourse in Grenoble set the paradigm under which the later campaign of evictions was about to happen. The notorious Circulaire IOC/K/1016329/ J of 24 June 2010 of the Ministry of Interior translated into actions the intentions expressed by the President. Evictions entailed immediate expulsions. Exceptions from the law were acceptable, as this was an extraordinary situation. The campaign of eviction was part of the war for preserving the values and the foundations of the French republic. The campaign was, under the President's terms, beyond issues of "majority, of left and right, of the President or of the mayor" (Discours de M. le Président 2010).

The problems faced by the Roma were framed as problems caused more by lifestyle and culture than by socio-economic inequality. By portraying them as outsiders and not citizens, politicians created room for policies that collectively targeted the Roma as a special case (Vermeersch 2012). Hence, it is justifiable to use exceptional, urgent measures that were outside normal politics against them (Bărbulescu 2012). The gravity and the urgency of the situation and the obvious character of the arguments made irrelevant a public debate on security and on the context,: "if I came here to tell you: they shot at police officers and I'm organising a debate, who would take me seriously?" (Discours de M. le Président 2010).

Data gathered by the European Roma Rights Centre (ERRC 2016) shows that both evictions and expulsions were undertaken by the French authorities in 2011 and 2012. For 2012, before November the 19th, almost 2700 people from Romania had received an expulsion order (Carrera 2013). One has to notice that, in May 2012, there was a change of Government in France, but the evictions and expulsions continued. The estimated number of Roma migrants forcibly evicted was 21,537 for $2013,14,483$ for 2014, and 11,128 for 2015 (ERRC 2017). In 2016, ERRC noticed a decrease in numbers of forcibly evicted, but an increase in the number of evictions without any legal court decision. More than half of evictions were undertaken on the basis of safety risk or health hazard notices issued by mayors or prefects which are not subject to automatic judicial review. As recent as September 2015, the United Nations High Commissioner for Human Rights expressed serious concerns about ongoing forced evictions of Roma and Travellers in a number of European States, including most recently France and Bulgaria (Office of the High Commissioner for Human Rights 2015). The same declaration appreciated that "It is becoming increasingly apparent that there is a systematic national policy to forcibly evict the Roma" (Office of the High Commissioner for Human Rights 2015). The document purposefully reminded that earlier in 2015, two key international Treaty Bodies, namely the Committee on the 
Elimination of Racial Discrimination and the Human Rights Committee, urged France to refrain from such forced evictions without the provision of alternative housing.

In the declarations given on the occasion of the visit of Romanian President Klaus Johannis to France in 2015, Francois Hollande specifically mentioned what he called "the sensitive problem of the Roma":

I have mentioned also the sensitive problem of the Roma. For several months, at the initiative of our governments, we have a more direct cooperation in what regards the Police. There is also an integration programme in Romania of this minority, a strategy was defined and we act, myself and the Romanian President, so that on European plan there could be further mobilisation. We have police representatives from Romania in France, to fight criminal networks and to impede certain types of traffic, notably the traffic of human beings. We have reaffirmed the will to regulate this issue with humanity and in a firm way. It was also very important to receive today President Iohannis who represents today for Romania a factor of unity. (Declaration commune 2015)

In the discourse of the French President the term "integration" takes also another association: that of policing. One can infer two underlying arguments in President's Hollande declaration. One the one side, it is implied that the Roma migration is a criminal problem. The other underlying argument is that the "Roma problem" is there because the Roma are not well integrated in their country of origin. This line of argumentation does not differ very much from the position of President Sarkozy at the debut of the 2010 campaign. The terms used are softer, but the direct association of an ethnic group - in its entirety — with crime is verbalised clearly. The interchangeable use of Roma and traffickers is still there, reference being made specifically to that of people trafficking. What is important to remember is that the collective expulsions have not until now been the outcome of criminal investigations. The majority of those sent back to Romania have not been proven criminals. There hasn't been any data put forward by the authorities to confirm whole communities of Roma undertaking people trafficking. There might well be networks of people traffickers operating in Romania and France that require a collaboration of the Police in the two states, but it is uncertain how this is a "Roma problem". The labelling of such activities as a response to the "sensitive Roma problem" gives though an indication of the alleged progress made by French authorities since 2010. In terms of rhetoric, it seems nothing much has changed. The discriminatory rhetoric withstood the change of government as well as the critiques.

Emphasis on integration in the country of origin and establishing bilateral agreements is not a new approach for migration policies in the Western European states. Before the accession of Romania and Bulgaria to the EU, in 2007, agreements were signed between the then French Minister of the Interior, Nicolas Sarkozy, and the governments of the two countries for the return and reintegration of Roma migrants, or IOM's voluntary return programmes. The programme did little to improve integration as it was mainly used by migrants to return to their home countries for short periods of rest before heading back to France (Nacu 2012). While before EU accession, the Romanian authorities had the task to filter out migrants, now policing happens in the country of destination and the home country police is involved. From the speech of the President Hollande, it was hard to distinguish another scope of the bilateral cooperation on the Roma other than policing. 
The President referred to the two issues as being a single one. This can be an indication of the paradigm of criminalisation and securitisation (Bărbulescu 2012; Nacu 2012; Van Baar 2014) present as well in President Sarkozy' speeches, and under which "free movement" is configured as a right for the "right kind of Europeans" and under which EU member states attempt to render Roma migrants irregular and deportable.

The continuation of collective evictions and expulsion from France of migrant Roma living in informal settlements, as well as the adoption of similar measures by other European Union member states (O’Nions 2011), can also be explained through the role this strategy has in responding to and in exacerbating the beliefs and fears regarding the Roma migrants. The presence of the Roma migrants is perceived as a threat, so the intervention of the authorities is framed under security arguments. No arguments are employed to confirm the risk posed by the Roma migrants, as the centuries old beliefs about the dangerous nature of the Roma are embedded in the culture of the majority population and seldom put under question.

\section{Discourses of Discrimination and Discourses of Integration at European Union Level}

By the beginning of September 2010, reactions from national and international institutions started to come forward. The French side's assurances were contradicted by the revealing in the French press of the circulaire which made it clear that state representatives in the French departments had received indications from the Government to target with priority Roma camps.

The statements issued at the highest level of European institutions in September 2010 expressed concerns over the expulsions both from a free-movement point of view as well as from a human rights point of view. Despite the initial emphasis on the unacceptable conduct of the French Government under human rights regulations, this issue faded away from debate at later stages. I will henceforth contrast the initial considerations in the response given by both the European Parliament and the Commission with the later recommendations for action and with the current situation. I maintain that, though acknowledged, the human rights abuse was not only left unsanctioned, but the abusive practice of ethnic targeted expulsions was upheld by national authorities with little consequences from the European Union. Hence, I further argue that a de facto exception of the migrant Roma from full enforcement of human rights legislation was accepted by both national and European authorities.

Like other resolutions of the European Parliament, the one adopted on September 9th 2010 on the situation of Roma and on freedom of movement in the European Union, was not legally binding for the member states. Nonetheless, the resolution indicated clear guidelines for coordination of the practices of expulsion with the Union's law and principles, and with international human rights law. ${ }^{1}$ The document

\footnotetext{
${ }^{1}$ The European Parliament resolution of 9th September 2010 refers to specific articles of the EU Charter of Fundamental Rights, in an order of the relevance for the given situation. Similarly are mentioned Articles 2 and 3 of the Treaty on European Union, which lays down the fundamental rights and principles underpinning the European Union, including the principles of non-discrimination and free movement. At the next point, the resolution refers to the Treaty on the Functioning of the European Union, starting with Articles 8, 9, and 10 which regard equality, social inclusion, and discrimination.
} 
refers to other EU laws regarding both discrimination and free movement, as well as to documents issued by European institutions and which concern the situation of the Roma. Points A to $\mathrm{L}$ of the resolution are an acknowledgement of the particular situation of the Roma in Europe. The first call to action, at point 1 of the resolution:

recalls that the European Union is above all a community based on values and principles designed to maintain and promote an open and inclusive society and EU citizenship, particularly by prohibiting all forms of discrimination (European Parliament 2010).

Through the document the European Parliament "emphasises the right of all EU citizens and their families to free movement and residence throughout the EU" (European Parliament 2010), and

expresses its deep concern at the measures taken by the French authorities and by other Member States' authorities targeting Roma and Travellers and providing for their expulsion; "urges those authorities immediately to suspend all expulsions of Roma, at the same time calling on the Commission, the Council and the Member States to intervene with the same request"; "emphasises that mass expulsions are prohibited by the Charter of Fundamental Rights and the European Convention for the Protection of Human Rights" (European Parliament 2010).

From the statements above, it is rather clear that the European Parliament considered the expulsions taking place in the summer of 2010 to be in gross violation of the right to non-discrimination and of the fundamental principle of the European Union. The European Commission had already initiated action before the Parliament's call. Vice-President Reading, heading the then newly established Directorate General for Justice, Citizenship and Fundamental Rights, and Commissioners Malstrom and Andor had issued a joint statement on the 1st of September (European Commission 2010). This document included a preliminary legal analysis section which emphasised that it was the primary responsibility of Member States to ensure public order and the safety of their citizens on their national territory, conditioned by the respect of the commonly agreed EU rules. Moreover, any measures taken by Member States therefore had to be assessed in the light of EU rules on free movement, non-discrimination and the EU Charter of Fundamental Rights. The next point stated the evident responsibility in front of the law of citizens who did not comply with it, but also that it was "equally clear that nobody should face expulsion just for being Roma" (European Commission 2010). The Commission took the responsibility to analyse whether the measures taken by the French authorities were fully compliant with EU law, Rights and Fundamental Freedoms, and that such measures were in violation of the EU Treaties and EU law, since they amounted to discrimination on the basis of race and ethnicity (European Commission 2010).

In terms of actions, the Commission proposed "to watch over the conformity of all Member States' measures taken with regard to Roma with EU law on free movement, non-discrimination and the EU Charter of Fundamental Rights" (European Commission 2010). At points "b" to "e "of the actions list, there is a shift towards common Roma subjects: creation of a Task Force for EU funds for Roma integration, 
intensified dialogue with representatives of the Roma community, the risk of human trafficking among the Roma. As one can tell, these are not any longer proposed solutions for tackling the alleged violations of law by the French authorities but rather solutions for the socio-economic situation of the Roma in general. It is rather unclear how these long-term desiderata would help in the face of the gravity of accusations against the Government of an EU Member State. What these measures do is to shift the discussion from the violations of the rights Roma have as humans and as equal citizens of the European Union towards a discussion about the particularities of the Roma. This is not far in terms of rhetoric from invoking the popular discourses about the Roma which were discussed in the previous section of this paper.

The position of the Commission became more categorical after the circulaire was revealed in the French press and after the French Secretary of State for European Affairs made the remark that "the Guardian of the Treaties is the French People" (Romagate 2010). Vice- President Reding did not stop short from qualifying the actions of the French Government "as a disgrace" and insisted on the gravity of law violations. The Vice president of the Commission concluded that she was personally convinced that the Commission will have no choice but to initiate infringement action against France: "for a discriminatory application of the Free Movement Directive" and "for lack of transposition of the procedural and substantive guarantees under the Free Movement Directive" (SPEECH/10/428 Viviane Reding 2010).

The one-day European Council on the 16th of September, just two days after Vivianne Reding's speech, was dominated by the so called Roma controversy (Carrera 2013). Unfortunately, the harsh stance taken by the Commissioner opened the way for French authorities to take the debate in a very different direction. President Sarkozy considered that Vice President Reding had insulted France and expected excuses. The Commission maintained its position and, on the 29th of September, issued a formal notice to France requesting the full transposition of the Citizens' Directive 2004/38. It included an ultimatum until the 15th of October for the French authorities to provide draft transposition measures and a transposition schedule, unless infringement proceedings would be opened.

Meanwhile, the French Government had continued the campaign of evictions of camps and immediate expulsions of their occupants. On top of this, the French press revealed that the gendarmerie had created a data base of onal information on migrants which included reference to ethnicity. The data base described high-risk groups by mentioning both the French gens to voyage and Eastern European Roma (Johannes 2010). Despite the fact that French authorities had continued the violations, by the mid of October, the conflict between the Commission and the French Government was defused. Infringement proceedings were not initiated, and both sides claimed victory (European Commission 2010). At the same time, the Commission claimed not to have obtained objective, material, and concrete evidence in what concerned discrimination. This opinion is not reflected in the text of the official communication MEMO/10/502.

In April 2011, the Commission acted on the commitment it took in the Joint Information note at point 44.b., and formally adopted the EU Framework for National Integration Strategies up to 2020 (European Commission 2011). One main critique of the Framework is that it does not cover the EU citizen of Roma origin exercising the freedom to move between EU Member States. If it were to be considered the direct 
effects it has on the discrimination of migrant Roma within EU, the framework is not relevant. Any impact it might have is indirect and, nonetheless, on the long term. Despite the evidence that the evictions and expulsions have continued as indicated in several reports by institutions and NGOs (Amnesty International 2013) ${ }^{2}$, the Commission had reached by 2013 the conclusions that:

the situation has changed considerably in the last few years. Further to the Commission's action in 2010 to guarantee the application of free movement directive by all Member States, and to put in place a European Framework for National Roma Integration Strategies, France modified its law to guarantee full compliance with the free movement directive, notably as concerns procedural safeguards related to expulsions of EU citizens, and adopted its national Roma Integration Strategy. On the basis of this new Strategy, close cooperation and enhanced efforts on Roma inclusion is taking place with the active participation of France. (European Commission 2013).

In terms of wording chosen for the report, one can notice the lack of reference to allegations of discrimination and collective expulsions. One first argument why such reference should have been made is that these allegations were present in the declarations of the Parliament and of the Commission. Secondly, the report itself concerned the application of the EU Charter of Fundamental Rights. The Charter does not use the term integration specifically but in the case of people with disabilities, at Article 26. As there was no reference to discrimination, though the events in 2010 were purposefully mentioned, one can argue that the report does not distinguish between discrimination and integration and uses the later as a synonym for the former. Even so, it is still unclear how had the situation "changed considerably" in the case of discrimination. Discrimination was not part of the national integration strategies and was not part of the reporting actions of the Member States. The French National Integration Strategy, which the report names, did not cover the discrimination and fundamental rights challenges inherent to the situation of immigrant Roma (Carrera 2013). One is left to wonder if the change of law had made any difference for the Roma migrants, especially that the evictions and expulsions had continued. The report does not cover this issue, nor does the Roma Integration Strategy.

\section{Integration as Exclusion}

As previously mentioned, even the first declarations on the issue from VicePresident Reding linked the situation to the integration of the Roma. The Joint Information Note on the 1st of September, at point F. Next steps listed 5 action points, all of which referred to Roma. Only the first action made direct reference to

\footnotetext{
${ }^{2}$ Ombudsman (Défenseur des Droits); National Consultative Human Rights Commission (Commission nationale consultative des droits de l'homme, $\mathrm{CNCDH}$ ); the Inspectorates General (Inspections Générales: IGA [administration], IGAS [social affairs], CGEDD [environment and development] et IGAENR [national education and research]); Collectif National Droits de l'Homme Romeurope; League of Human Rights (Ligue des Droits de l'Homme, LDH); and the European Roma Rights Centre (ERRC).
} 
the Commission watching over the Member State's observance of the right of free movement and of the right to non-discrimination. The rest of the paragraph, as well as all other actions concerned Roma integration. Once the issue of violation of the fundamental rights of the Roma got lost in the high-level politics debate in Brussels, the categorical condemnation of the discriminatory actions of the French Government was later altogether replaced with debates over the integration of the Roma. As I mentioned before, though a relation between lack of integration and discrimination and violation of rights by state authorities might be established, it is unclear how projects of integration which produce effects on the long term would have been the adequate response for the immediate cessation of fundamental rights violation.

Anti-discrimination seems to be the important absence in the 2011 EU Framework Communication which has the explicit goal of guiding social inclusion. An Open Society Foundation policy assessment of the Framework concludes that the document "misses out the vital element of combating prejudice and discriminatory behaviour towards Roma" (Open Society Institute 2011). The Commission appeals to the member states for implementation of policies, but the document does not take into consideration that the national governments might lack even the mere political will to put the Roma issue on their agenda. As this paper has shown, governments do not hold back from exacerbating the deep-rooted anti-Roma sentiment. When dealing with the campaigns of collective evictions and expulsions, the Commission did not demonstrate to be unequivocal in its reaction to discriminatory behaviour by member states. The Framework Communication does not list existing legal instruments and measures to fight against discrimination at EU level. It is up to the Commission to pursue rigorous monitoring of the implementation of Racial Equality Council Directive 2000/43/EC.14, but practice has shown that this can be a highly politicised process (Open Society Institute 2011).

The absence of anti-discrimination in the Framework can be linked to what Sobotka and Vermeersch (2012) consider new assumptions at the basis for EU action to encourage Roma inclusion. Namely, the EU increased emphasis on socio-economic inclusion in order to change matters more profoundly and more rapidly for the Roma, while still engaging in promoting norms on anti-discrimination and fundamental rights. The Framework fails though to make any reference to the historical or cultural contextualisation of the notion of integration (Goodwin and Buijs 2013). The document does state from the beginning that "the current condition of Roma living in Europe now is unacceptable", and that "many of the estimated 10-12 million Roma in Europe face prejudice, intolerance, discrimination and social exclusion in their daily lives" (European Commission 2011).

The rest of the document focuses on the economic advantages of Roma inclusion almost as if it were a selling point for governments to make the extra effort. There is no consideration on how the mentioned intolerance and discrimination are not only a consequence of economical exclusion, but a cause of it too. The document puts forward an expectation that inclusion will take place with the help of European Union funding and an extra effort of good will on both sides. The paradigm of the Framework of Roma Integration is that the role of the EU is to highlight the issue and facilitate a high-level policy discussion about it. Having been committed to the larger common goal of membership, independent member states are expected to 
accept the norms and will cooperate for the development social policies and use more of the available funding for the benefit of the Roma population (Vermeersch 2012). The 2010 events concerning the Roma migrants are just one episode of the many in the post 2008 economic downturn EU which contradict the expectation that the member states are willing to conform to norms out of a concern about their reputation and therefore responsive to shaming by the other EU political actors (Schimmelfennig 2001).

Additionally, the Framework does not take into account that, for minorities, political status is regulated by perceptions of belonging. Other than the formal recognition by the state of membership to a political community, the majority's recognition of one's belonging conditions the fruition of participation, identity, and rights. Minorities such as the Roma migrants from Eastern Europe are not perceived as belonging (McGarry 2017) despite the legal status, i.e. European Union citizens enjoying the right of crossing freely the EU member states borders.

Critics of the European Union policy on the Roma (Y1ldiz and De Genova 2017; van Baar 2011; Sigona 2011) point out that discrimination and exclusion, and the various forms of subordinate "inclusion", seem to reinforce each other. By defining the policy target group mainly through social criteria such as poverty, exclusion, and marginalisation, the social stigma invoked by these criteria falls on the entire Roma minority (Mirga-Kruszelnicka 2017). The lack of any reference to the migrant Roma, and the continuous limitation to policies in the country of origin, seem to indicate a failure to acknowledge spatial mobility as an answer to the barriers for socio-economic mobility in the state of origin. In this context, the European Union Framework and its focus on inclusion can be interpreted as yet another example of how particularism of the member states is stretched at the level of the entire Union. Roma policies seem to produce a group which in itself is "the problem", "a European problem" in this case (Y1ldiz and De Genova 2017).

\section{Conclusion}

The case study of the French expulsions and evictions casts a shadow of doubt over the EU's capacity to turn into reality aspirations of unity in diversity and to act upon its anti-discrimination principles. While for a vast majority of the Roma, spatial mobility is undesirable and criminalised, and the decade-long plans for integration in the home country fail to show results, there seem to be little solutions left for breaking the trap of mutually reinforcing patterns of poverty and discrimination. Rather on the contrary, discrimination was reframed in order to project an essentialised view of a homogeneous, problematic, or even threatening Roma population. This re-framing thereby "naturalised" and "normalised" the separation of Roma from others and "defined" who and what constitutes a European (Plaut 2012). The discourses of integration do not imply a responsibility for the respect of the rights of the Roma, but rather the expression into a European Union framing of the discourses of the deviant Roma. The prevalence of the "inclusion" and "integration" discourse in settling the issue of discrimination of this category of migrants at the European level has to be looked at in the framing of the centuries of Roma exclusion and of the criminalisation of migration of the poor. 
Open Access This article is distributed under the terms of the Creative Commons Attribution 4.0 International License (http://creativecommons.org/licenses/by/4.0/), which permits unrestricted use, distribution, and reproduction in any medium, provided you give appropriate credit to the original author(s) and the source, provide a link to the Creative Commons license, and indicate if changes were made.

\section{References}

Amnesty International (2013). Told to Move On. Forced Evictions of Roma in France. Amnesty International Publications 2013.

Anderson, B. (2013). Us and Them?: The Dangerous Politics of Immigration Control. OUP Oxford.

Bărbulescu, H. (2012). Constructing the Roma people as societal threat. The Roma expulsions from France. European Journal of Science and Theology, 8(Supplement 1), 279-289.

Bigo, D., Carrera, S, and Guild, E. (eds).(2013). Foreigners, Refugees Or Minorities?: Rethinking People in the Context of Border Controls and Visas: Ashgate Publishing Company.

Carrera, S. (2013). The Framing of the Roma as Abnormal EU Citizens. In Guild E., Rotaeche C., Kostakopoulou D (ed.) The Reconceptualisation of European Union Citizenship.

Chilton, P. (2004). Analysing political discourse: Theory and practice. London: Routledge.

Declaration Commune avec M Klaus Werner Iohannis, President De Roumanie. (2015). Retrieved from http://www.elysee.fr/declarations/article/declaration-commune-avec-m-klaus-werner-iohannis-presidentde-roumanie/". Accessed Nov 2015.

Discours de M. le Président de la République à Grenoble - Prise de fonction du nouveau préfet. (2010). Retrieved from http://www.elysee.fr/president/root/bank/pdf/president-9399.pdf. Accessed Nov 2015.

ERRC. (2016). Recent Forced Evictions in France: the Calm before the Storm, Retrieved from http://www. errc.org/article/recent-forced-evictions-in-france-the-calm-before-the-storm/4498. Accessed January 2017.

ERRC. (2017). Written Comments of the European Roma Rights Centre Concerning France. European Roma Rights Center.

Essed, P. J. M. (1991). Understanding everyday racism: an interdisciplinary theory. Newbury Park: Sage.

Euronews. (2010). Riots in French City after Police Shooting, Euronews, Retrieved at http://www.euronews. com/2010/07/17/riots-in-french-city-after-police-shooting

European Commission (2010). MEMO/10/502 Statement by Viviane Reding, Vice-President of the European Commission, EU Commissioner for Justice, Fundamental Rights and Citizenship, on the recent developments concerning the respect for EU law as regards the situation of Roma in France, Press Releases Database, Retrieved from http://europa.eu/rapid/press-release_MEMO-10-502_en.html. Accessed Nov 2010.

European Commission. (2011). Joint Information Note by Vice-President Viviane Reding, Commissioner Laszlo Andor and Commissioner Cecilia Malmstrom F. 44. A (2011) . Retrieved at http://www. statewatch.org/news/2010/sep/EC-Roma-France-report.pdf. Accessed Nov 2015.

European Commission. (2013). Report From the Commission to the European Parliament, the Council, the European Economic and Social Committee and the Committee Of the Regions 2012 Report on the Application of the EU Charter of Fundamental Rights.

European Committee of Social Rights. (2004). COLLECTIVE COMPLAINT No. 27/2004 European Roma Rights Centre v. Italy. Retrieved from http://www.coe.int/t/dghl/monitoring/socialcharter/Complaints/CC27 CaseDoc1_en.pdf. Accessed Nov 2015.

European Parliament. (2010). European Parliament resolution of 9 September 2010 on the situation of Roma and on freedom of movement in the European Union, Retrieved from http://www.europarl.europa. eu/sides/getDoc.do?pubRef=-//EP//TEXT+TA+P7-TA-2010-0312+0+DOC+XML+V0//EN. Accessed Nov 2015.

Fekete, L. (2014). Europe against the Roma. Race \& Class, 55(3), 60-70.

Goodwin, M., Buijs, R.( 2013). Making good European citizens of the Roma: a closer look at the EU framework for National Roma Integration Strategies. German Law Journal, (14).

Haslam, N., Rothschild, L., \& Ernst, D. (2000). Essentialist beliefs about social categories. British Journal of Social Psychology, 39(113), 127.

Johannes, F. (2010). Le fichier des Roms du ministère de l'intérieur, Libertés Surveillées. Retrieved from http://libertes.blog.lemonde.fr/2010/10/07/le-fichier-des-roms-du-ministere-de-linterieur/. Accessed January 2017. 
Liberation. (2010). A Saint-Aignan apres la bataille, Liberation, Retrieved at http://www.liberation. fr/societe/2010/07/20/a-saint-aignan-apres-la-bataille_667204. Accessed Nov 2015.

Manners, I. (2003). Normative Power Europe: A Contradiction in Terms?. Social Science Research Network. Retrieved from http://papers.ssrn.com/abstract=316064

Martínez Guillem, S. (2011). European identity: across which lines? Defining Europe through public discourses on the Roma. Journal of International and Intercultural Communication, 4(1), $23-41$. https://oi.org/10.1080/17513057.2010.533788.

McGarry, A. (2017). Romaphobia: The last acceptable racism. London: Zed.

Melis, B. (2001). Negotiating Europe's Immigration Frontiers (1 edition). Springer.

Ministry of Interior. (2010). Ministre de l'Immigration, d l'intégration, de l'identité nationale et du développent solidaire, E. Besson a propos de 1 'évacuation des campements illicites, 30 August 2010. Retrieved from http://www.immigration.interieur.gouv.fr/Archives/Les-archives-du-Cabinet-de-M.-EricBesson-2009-2010/Les-discours-du-Cabinet-de-M.-Eric-Besson-2009-2010/Aout-2010/Discours-d-EricBESSON-lors-de-la-conference-de-presse-du-lundi-30-aout-2010-a-propos-de-1-evacuation-descampements-illicites. Accessed Jan 2017.

Mirga-Kruszelnicka, A. (2017). Revisiting the EU Roma Framework: Assessing the European Dimension for the Post-2020 Future. Open Society Foundation. Available online at: https://www. opensocietyfoundations.org/sites/default/files/revisiting-eu-roma-framework-20170607.pdf. Accessed 21 April 2018.

Nacu, A. (2012). From silent marginality to spotlight scapegoating? A brief case study of France's policy towards the Roma. Journal of Ethnic and Migration Studies, 38(8), 1323-1328. https://doi.org/10.1080 /1369183X.2012.689192.

O’Nions, H. (2011). Roma expulsions and discrimination: The elephant in Brussels. European Journal of Migration and Law, 13(4), 361-388. https://oi.org/10.1163/157181611X605864.

Office of the High Commissioner for Human Rights. (2015). Zeid urges France, Bulgaria to halt forced evictions of Roma. Retrieved from http://www.ohchr.org/EN/NewsEvents/Pages/DisplayNews. aspx?NewsID=16409\&LangID=E\#sthash.fAv52eh6. Accessed Nov 2015.

Open Society Institute- Brussels. (2011). Policy Assessment EU Policies for Roma Inclusion. Retrieved from tyfoundations.org/sites/default/files/2011-07\%2520EU\%2520Roma\%2520Inclusion\%2520Policies\% 2520final.pdf. Accessed Nov 2015.

Plaut, S. (2012). Expelling the victim by demanding voice. Alternatives: Global, Local, Political, 37(1), 5265. https://doi.org/10.1177/0304375412439676.

Richardson, J. E., \& Wodak, R. (2009). Recontextualising fascist ideologies of the past: right-wing discourses on employment and nativism in Austria and the United Kingdom. Critical Discourse Studies, 6(4), 251267.

Riesigl, M., Wodak, R. (2009) The Discourse Historical Approach. In: Wodak, R. Meyer, M. (ed), Methods of Critical Discourse Analysis, Second Edition, Sage.

Romagate teaching from Pierre Lellouche. (2010). Retreived from http://grahnlaw.blogspot.nl/2010/09 /romagate-teaching-from-pierre-lellouche.html. Accessed Nov 2015.

Schimmelfennig, F. (2001). The community trap: liberal norms, rhetorical action and the eastern enlargement of the European Union. International Organisation, 55, 47-80.

Sigona, N. (2011). The governance of Romani people in Italy: discourse, policy and practice. Journal of Modern Italian Studies, 16(5), 590-606.

Sobotka, E., \& Vermeersch, P. (2012). Governing human rights and Roma inclusion: can the EU be a catalyst for local social change? Human Rights Quarterly, 34, 800-822. https://doi.org/10.1353/hrq.2012.0050.

SPEECH/10/428 Viviane Reding. (2010). Retrieved from http://europa.eu/rapid/press-release_ SPEECH-10-428_en.htm. Accessed Nov 2015.

Tervonen, M., \& Enache, A. (2017). Coping with everyday bordering: Roma migrants and gatekeepers in Helsinki. Ethnic and Racial Studies, 40, 1114-1131. https://doi.org/10.1080/01419870.2017.1267378.

Triandafyllidou, A. (2001). Immigrants and national identity in Europe. London: Routledge.

van Baar, H. (2011). Europe's romaphobia: problematization, securitization, nomadization. Environment and Planning D: Society and Space, 29(2), 203-212.

Van Baar, H. (2014). The centripetal dimension of the EU's external border regime. Etnofoor: Anthropological Journal, 26(2), 8793.

van Dijk, T. (1984). Prejudice in Discourse. An Analysis of Ethnic Prejudice in Cognition and Conversation. John Benjamins B.V. Amsterdam, Philadelphia.

Verkuyten, M. (2003). Discourses about ethnic group (de-)essentialism: oppressive and progressive aspects. British Journal of Social Psychology, 42(3), 371-391. https://doi.org/10.1348/014466603322438215. 
Vermeersch, P. (2012). Reframing the Roma: EU initiatives and the politics of reinterpretation. Journal of Ethnic and Migration Studies, 38(8), 1-18. https://doi.org/10.1080/1369183X.2012.6.

Yıldız, C., \& De Genova, N. (2017). Un/free mobility: Roma migrants in the European Union. Social Identities, 24, 425-441. https://doi.org/10.1080/13504630.2017.1335819. 